\title{
Democratizing the Dramatic Text: Wannous's Late Aesthetics and Individual Freedom
}

\author{
Samar Zahrawi \\ Department of World Languages and Cultures \\ College of Humanities and Social Sciences \\ Sam Houston State University, TX, USA. \\ Email: szahrawi@shsu.edu
}

Received:1/4/2021

Accepted: 2/9/2021

Published: $2 / 24 / 2021$

\begin{abstract}
Sadallah Wannous (1941-1997), the Arab World's most celebrated dramatist, gave up on the didactic art of the 'theater of politicization', in the middle of his career, in favor of a freer introspection of human psyche and passions. He spent his most prolific late years searching for new aesthetics and promoting a culture of free thinking. Abandoning his prior commitment to achieving the modern state, Arabic unity, the liberation of Palestine and the triumph of communism, he started creating individuals who are caught up in conflicting passions, loyalties and choices. However, his new themes will still betray a will to reform the many ailments in Arabic culture and politics, such as politico-religious coalitions and colonialism. This article will study the artistic and ideological transformation in Wannous's later drama. It will also explore the later pro-democracy trends through analyzing the emerging individualism in characterization and the plurality of discourses in the plays of the later period 1989-1997, namely The Rape (1989), Historical Miniatures (1993), Miserable Dreams (1994), Rituals of Signs and Transformations (1994), and Drunken Days (1997).
\end{abstract}

Keywords: democratization of the dramatic text, intellectual freedom in Syrian drama, late plays of Sadallah Wannous, plurality of voices in theater, Sadallah Wannous, Syrian theater, Syrian drama

Cite as: Zahrawi, S. (2021). Democratizing the Dramatic Text: Wannous's Late Aesthetics and Individual Freedom. Arab World English Journal for Translation \& Literary Studies 5 (1) 3-19. DOI: http://dx.doi.org/10.24093/awejtls/vol5no1.1 


\section{Introduction}

How can democracy replace autocracy after long decades of dictatorship? This is the concern of the leading Syrian dramatist Sadallah Wannous (1941-1997), who was most dedicated to instigating a revolution and attaining freedom through his dramaturgy. His journey of ideological and artistic transformation is inspiring, as it points to the painstaking process of education and awareness that democracy requires. Syria, as a young state, newly independent from the French mandate in 1943, suffered from the repercussion of colonialism and struggled with neocolonial interventions that sponsored multiple coups from 1949 till 1971 and deterred the instillation of democratic rules (Wakim, 2013, pp. 89- 96). Controlled by dictatorships for over seven decades, Syrians underwent multiple forms of oppression. Freedom of expression has been repeatedly deemed as national treason. Many freethinkers lost jobs and even lives for candidly criticizing the government (Kahf, 2001, p.8). As a result, the public, for a long time, resorted to silence and passivity. When the revolution, that Wannous persistently propagated for in his theater of politicization, finally erupted after his death in 2011, it brought about not a democracy, but the worst human and economic crisis in modern times: nine years of war, 12 million displaced individuals, half a million killed, and grand scale destruction. Such catastrophic results had been foreseen only by few intellectuals who championed truth and freedom as the only way to combat oppression. Although advocated for by numerous thinkers, such democracy was unreachable. The path to intellectual freedom under hard-core totalitarianism is not easily accessible, as writers needed to rid themselves of multiple layers of indoctrination and ideological constraints. One example is Sadallah Wannous who developed a very strong stance against the autocracy of dictatorship and religo-political alliances. He and many other contemporary writers took refuge in a Marxist ideology that seemed to promise the panacea against the financial exploitation of the impoverished masses. It is during the last seven years of his lifetime that he acquires the broadness of vision to branch out and embody the concept of freedom on multiple levels, the individual as well as the political. As his middle period plays are written in the Brechtian tradition that call for moving from the word to action, he concluded, towards the end of his career, that theater cannot effectuate a revolution against oppression. Rather, it can only have an enlightening role. To lay grounds for democratic education and reasoning within a totalitarian-ruled society, Wannous in his late plays created dramatic dialogues informed by a plurality of perspectives. Allowing for a multiplicity of voices, the dramatist shifted his focus from his earlier insistent calls for revolution against dictatorship to advocating for the individual's assimilation of personal and intellectual freedom.

\section{Wannous's last period: Transformation from an Instigator to an Edifier}

In the middle period of his writing for the stage (1968-1978), Wannous devised the theater of politicization and theorized for it in his Manifestos for a New Arabic Theater (1970). This theater is a "response to systematic oppressive regimes" (p. 107). It discusses political issues through their "inherent laws and intertwined relations within the economic and political structure of society" (p. 91). At the same time, it tries to "discover a progressive milieu in which such issues can be solved" (p. 92). Inspired by Carl Marx and Berthold Brecht, his middle period plays (1968- 
1978) aimed at politicizing the common people who are kept ignorant and ineffective by the oligarchies. It is this stratum of the oppressed people that Wannous hopes will one day "champion revolution and change" (Wannous,1970, p. 92). Falling short of his initial aim at mobilizing the masses through theater, Wannous receives a second blow as he learned about President Anwar Sadat of Egypt signed a peace treaty with Israel. His frustration in effectuating change is only extenuated by his despair of any chance that the Palestinian people can ever reclaim their homeland. Surviving from a suicidal attempt, he gave up writing for the stage for ten years, during which he worked as a journalist and reassessed his political stances. He found that his obsession with the Marxist class struggle had removed him away from due concern with the individual. His awareness that no democracy can be attained unless the individual in brought back to the center stage again informs his later writing and formed is new aesthetics.

When he took up writing again in the last seven years of his life, the freedom that he always called for is clearly more organically fused into his writing. It took this champion of freedom a lifetime to internalize freedom and become less dogmatic. As he was battling cancer, he broke free from the inner censor, sexual taboos, Marxist doctrine and many more dogmas. His late plays feature multiple voices that argue cogently from a plurality of perspectives. Such dramaturgy manifests a growth of the democratic spirit, that was missing in his earlier theater of politicization. In an interview, Wannous explains that his silence upon losing his project and undergoing severe transformations, gave him the ability to adapt and to reinvent himself for the stage. Democracy is still a far-fetched dream, but he is confident that freedom of thought and expression is an essential step of the long road:

I feel horrified when I think about my life. Except for the two or three years towards the end of the fifties, I do not have a recollection of a period that allowed me to flourish, or to express myself freely. I was too young then when democracy was not an essential issue for my being. I am filled with horror for myself and for many generations that go through life without the chance to be free and open, or to build their awareness in a lively atmosphere enjoying dignity and geography. I am more motivated to be silent than to write... Losing belief in one's ability to effectuate change, a writer would lose the incentive to write. You should not forget that I am one of a generation of writers that made a grave mistake when they made a strong connection between their artistic creativity and their political efficacy. (Wannous, 1986, p. 453)

After a long period of reassessment, Wannous came to the conviction that theater is not a tool of revolution, but that of spreading knowledge (Wannous, 1970, pp. 114-115). "The effectiveness of theater now does not lie in its preoccupation with the quick revolutionary change, but in its ability to function as a medium of enlightenment, which can broaden the audience's horizon. It is a means of cultivating aesthetic values which are at odds with these propagated by public media" (Wannous, 1970, pp. 114-115).

Arab World English Journal for Translation \& Literary Studies 
In such a period of transformation, personal freedom and the psyche of the individual are blatant features His theatre of the 1990s makes a clear break from that of the 1960s and 70s with its astonishing freedom in its subject matter and boldness in its themes and language (Al-' Anezi, 2006, p. 203). Admiring Taha Hussein (1889-1973), the prominent controversial and secular Egyptian writer, Wannous adopts his project of modernization and democracy:

No rational thinking without science and rejuvenation of reason. No blooming of science without freedom. No freedom without secularism. No secularism without modernization of state and propagation of democracy. The latter can only be attained by creating a civil society based on national unity and fair distribution of economic and political privileges (Wannous, 1990, pp. 492-3).

Hence, his late characters break social, political and religious taboos. They communicate a diversity of intellectual perspectives and a multiplicity of voices. With his new expansion towards multiple variations on the theme of freedom, it is almost impossible to categorize his last plays under one form, but they can all be described as promoting democracy and civil society through allowing pluralism and expressing individual and libidinal freedom.

The most prominent feature of change in Wannous's later dramaturgy is avoiding earlier direct didacticism where the authorial voice is ascribed to minor characters who break the fourth wall and directly preach the playwright's message. For example, the running commentary of Anwar in Soiree with Abi Khalil al-Qabbani (1973) polemically argues for the role of theater in intellectual freedom: "Theater solidifies people's inclination to get together because it minimizes conflicts and fanaticism and urges them to unite and socialize. (Wannous, 1973, p. 756). In a similar polemical oratory, the actors in King's Elephants (1969), break the fourth wall and exhort the audience to rebel against oppression in order to prevent a "bloody and violent story" (p. 579). These two examples of polemical dramatization are cited here in order to serve as a ground of comparison to show the way Wannous's later dramaturgy internalizes the concept of freedom and imbeds it organically in his dramatic techniques.

In his late period, Wannous changed from an instigator to an edifier, from Marxism to freedom from dogmas. In this most prolific period, he produced eight plays The Rape (1989), Historical Miniatures (1994), A Day of our Time (1994), Rituals of Signs and Transformations (1993-4), Miserable Dreams (1994), Mirage Epic (1995), Countries Narrower than love (1996), and Drunken Days (1997). These plays enlighten the audience about multiple issues, ranging from the political to the personal. They reveal an increasing focus on the individual's response to social repression. "For the first time in his last plays, Wannous takes special care to build complex characters that are full of life and rich in social, human and psychological features" (Abboud, 2008, p. 66). During his terminal illness (1992-1997), Wannous's focus turned on the individual, thus making a clear break with his earlier Marxism which had ascribed all human strife to class struggle

Arab World English Journal for Translation \& Literary Studies 
and considered focusing on the self a bourgeoisie Indulgence. (Al-'Anezi, 2006, p. 276). At this stage of transformation, the playwright learns that delving into the self is a way of freeing himself from the dogma of 'isms' and that concealing individuality is counter effective to building a free civil society. In an interview with Mary Ilyas, he admits:

I discovered that we live with the idea that we should tame our individuality for the purpose of social integration. I have been working against my individuality all my life... How wrong is that and to what extent this depletes our creativity! A society that suppresses the benign uniqueness of the individual, will necessarily be poor, backward and incapable of forming a pluralistic civil society. (Ilyas, 200 p. 19).

His later dramatic conflicts and themes reveal his liberation from the narrowness of Marxism and his inclusion of the concept of freedom in all facets of life.

As Wannous evolved, his later plays focus on expressing the self and they significantly depart from the earlier and middle plays in techniques, characterization, and range of themes. In a study of the individual and autobiographic elements in Wannous later plays, Souleman observes that "the character occupies the front of the theatrical scene, and the individual performs the act of revelation and exposure of the self, which is the foundation of the dramatic discourse.(Spring 2015, p.1). The search for truth and freedom in the later plays transcends the cultural taboos and allows for introspection into libidinal passions and fantasies as well as individual and social interactions. Approaching these two themes, Wannous ended his plays with the total collapse of the characters' worlds. Such a collapse is ascribed to the "tension between the self and the other, between the private and the public, and between the individual and the collective". (Souleman, spring 2015, p. 1). Delving deep into the psyche of the characters, Wannous studies the influence of traditional social values, religious taboos and political oppressions on the freedoms afforded for individuals resulting in hypocrisy or suppressions. The personas in these plays seek freedom and truth but never achieve them. Thus, they end up with frustrations and utter failures, which explain why all these plays are tragedies ending with death or despondence.

\section{First Stage of Democratic Characterization: The Rape}

The Rape (1989) marks Wannous's first departure from the theater of politicization and the Brechtian Epic theatre. The once relentless opponent of Israel, who attempted a failed suicide at the news of peace treaty between Egypt and Israel, is now able to envision a dialogue between Israeli and Palestinian discourses, thus expanding his vision to include the other. His main concern invariably remains in solidarity with the justice of the Palestinian people. The weight of the final message lies in the incrimination of the unjust policies and practices of both the Israeli government as well as Arabic regimes. However, what revolutionizes his approach is the innovation in which he humanizes the Israeli citizens, presents them in an empathetic light, and widens the scope of voices in his dramaturgy.

Arab World English Journal for Translation \& Literary Studies

ISSN: 2550-1542 | www.awej-tls.org 
Inspired by the Spanish playwright Antonio Buero Vallejo's The Double Life of Dr. Valmy, 1978 (Al-Anezi, p. 207), The Rape presents a dual story of Palestinian and Israeli characters who are equal in dramatic grandeur. The Palestinian characters, such as Dalal, Al-Fare'a, and Isma 'il, are victims of displacement and loss of land. They become activists who are consequently tortured by the Israeli police force and acquire heroic/martyr status. The Israeli characters, such as Isaac, Rahil, and the psychiatrist Dr. Manouhin are intrinsically conscientious individuals burdened by humanitarian concerns as they own their ethical responsibility towards Palestinians. The security officer, Isaac, who is assigned to torture and rape Palestinian prisoners, eventually suffers from sexual dysfunctions and an excruciating sense of guilt. His wife Rahil wakes up to the injustices done to Palestinians upon establishing the state of Israel and decides to leave the country. The narrator, Psychiatrist Dr. Manouhin, acting as the moral compass, instructs Rahil to convey the truth to the world, so that "we will not be an accomplice with them. We will not allow them to confiscate the future" (Wannous, 1989, p. 163). The innovation here lies not in compromising on an earlier political pro-Palestinian stance, but obviously in the author's willingness to negotiate a more democratic and pluralistic characterization by allowing voice to the 'other'. The author's notes show that he deliberately aimed at equal gravity of the Israeli and Palestinian personas:

Both plots interweave and grow reciprocally. I am dreaming of two distinctive performances, one characteristically Israeli, and the other characteristically Palestinian. Both performances should be earnestly genuine. Here, I warn against any grotesque dramatization of Israeli characters. I also warn against hyperbolic acting or hostile presentation (Wannous, 1989, p. 64).

In this, Wannous is a pioneer in democratizing the dramatic text and allowing for a wider perspective. However, despite this innovation at plurality of voices, both stories are still controlled by his leftist anti-Israeli ideology, and his belief in the fairness of the Palestinian cause. Thus the play does not democratically reveal two opposing perspectives. The play presents the Palestinians as victims of dispossession and torture, while the sympathetic Israeli characters are victims of a Zionist ideology that indoctrinates them with hatred and supremacy. For example, while treating the guilt-ridden security officer, Isaac, from sexual incompetence, Dr. Manouhin argues that Isaac, after participating in the torture and rape of Palestinian freedom fighters, cannot salvage his conscience. When Isaac argues dogmatically that his actions were legal thus right, Dr. Manouhin argues for ethics rather than power:

My loyalty is to justice, not to the law; there is no justice in what you are doing. There is no justice in occupying another people's land and there is no justice in the Zionist severity on which the Israeli state was established. I refuse to accept what you are doing, no matter what the justification is. (Wannous, 1989, p. 114)

These Israeli characters are dramatized as conscientious liberalists who escape the brain-washing effect of the right-wing Zionists such as Meid, Jadoun and Sarah. Because of his ethical awakening,

Arab World English Journal for Translation \& Literary Studies

ISSN: 2550-1542 | www.awej-tls.org 
Isacc sympathizes with Arabs and loses his life when he requests to be discharged from his security forces (Wannous, 1989, p. 160). His wife, Rahil, is disillusioned with the foundational political perspective of the State of Israel, humanizes Arabs, and upon her husband's murder, decides to immigrate and advocate for truth and justice. (Wannous, 1989, p.162). The limited plurality of voices is a mark of Wannous's early stage of democratizing the text.

The novelty of this new approach is quite significant to Wannous's evolving freedom of thought. The main change of theme here is the call for justice for both Israelis and Arabs, while the censure falls solely on the governments on both sides. In lieu of his earlier uncompromising animosity towards Israel, he is now able to humanize liberal Israeli citizens while censuring only policies and governments. In this play "Zionism is a dilemma for Arabs and Jews alike" (Wannous, 1989, p. 165). For him, Zionism has an extension in the Arab dictators that "are oppressing their people" (p.166) and "are looting and squandering national resources" (p. 167). Merely by daring to present sympathetic Israeli characters, to call on his fellow Arabs to consider the possibility of peaceful coexistence with Israeli people, and to equate Arab regimes of the Middle East with Zionism, the playwright knew that he was inviting vilification and risking the reputation he had gained through his plays of the 1960s and 1970s. He was very aware of the danger of condoning the ideas of liberal Israelis, and was expecting to become subject to the "animosity of both the Israelis and the Arab Zionists" (p. 167). Most responses to the play ranged from bewilderment to hostility and outrage. "Those who retained the 1948 mentality attacked it vehemently as if it were a scandal or treason" (Al- Anezi, 2006, p. 215). Expecting a hostile reception to his empathetic Israeli characters, the playwright includes an interview between himself and the persona of Dr. Manouhin, in the epilogue, in which he meta-dramatically describes the challenges he encountered while creating the story. In this imagined interview, Wannous explains that he was changed and inspired by the attitudes and testimonies of some courageous Jews who opposed Zionism (Wannous, 1989, p. 164). To him Dr. Manouhin, like prophet Jeremiah [Irmia], is not betraying his people by opposing their politics. On the contrary, he is committed to protecting them from a moral dilemma. On the other hand, the persona of Dr. Manouhin posed extra challenges to the playwright who knew that the very idea of dramatizing him as an empathetic character from the enemy camp would be received by Arab audience as a treason:

I had to overcome so many obstacles such as historical suspicion, that denies your existence, political demagoguery, which denies your identity, the defeated people's phobia from treachery, the mayhem of victims and wounds, the possibility being hunted as a traitor". (Wannous, 1989, p. 165).

There can be little doubt that the Wannous of the 1960s and 1970s would have condemned the play. However, the evolved Wannous was aware of his role as a pioneer in breaking a political taboo and presenting a new daring and more democratic way of understanding people's diversity and regional politics. The fact remains that The Rape is a revolutionary step, although not yet complete, at creating equal standing and dialogue between Israelis and Arabs. 


\section{Second Stage of Democratic Characterization: Historical Miniatures}

As Wannous started presenting multiple truth and plural voices in The Rape, he refined this further in Historical Miniatures (1993). In this long play, dramatic conflicts grow in complexity and various characters, at opposite ends, equally express their perspectives cogently and eloquently. It is a historical play presenting the events of Tamburlaine's invasion of Damascus in 1401. However, the play, in fact, has contemporary relevance in issues such as national sovereignty and intellectual freedom. To that end, the playwright gives voice to a vast diversity of the society including the educated elite, progressive and Salafi clergy, statesmen, economic leaders as well as the common people.

Historical Miniatures starts with the news of Tamburlaine's army conquering Aleppo and moving towards Damascus. Expecting defeat, Damascus governor declares his will to surrender in order to save lives. However, the clergy, under the guidance of Tadheli, and the princes, under Azdar, decide to resist and defend the city against the instruction of the governor. As Tamburlaine's forces approach, the army of Sultan Naser Farah Bin Barqouq arrives to Damascus. However, the Sultan's soldiers start ransacking the city instead of defending it. The Sultan, after several victorious battles, withdraws and returns to Egypt in order to secure his throne in the face of civil unrest, thus manifesting the priority of his throne to the safety of his subjects. With the Sultan gone, people in Damascus are divided between two positions; resistance or surrender. People under the leadership of Prince Azdar and clergy Tadheli, fight Tamburlaine, and briefly take over the castle. The intellectual and financial elite, such as the famous historian Ibn Khaldūn and the merchant Dulama, decide to surrender in order to save their interests. Worried that Tamburlaine may hold him responsible for this split, Ibn Khaldūn, joins a committee of merchants and society leaders to present their loyalty to him with a great deal of expensive gifts. Tamburlaine accepts the surrender but imposes excessive tax, thus oppressing and impoverishing the people of Damascus. In the tumultuous situation of military invasion and consequent defeat, opposing voices rise to express the varying perspectives while dealing with the menace. Wannous's mastery and innovation, here, lie in allowing for a democratic presentation of all parties involved. For example, the perspective of the Clergy, Ibn Nabulsi, who pushes for surrender in order to protect the welfare of the city is proportionately counterargued by the Prince of the castle, Azdar, who fights for the honor and dignity for future generations. The conflict between both perspectives is resolved, as history denotes, in favor of surrender, thus the people of Damascus tragically cooperate with the Tatar army in destroying the castle of Damascus and ending the siege. The authorial voice is given to Ibn- Mufleh in his deathbed speech in which he reveals that the main reason for the downfall of Damascus is diminishing the civil society and debilitating the army which resulted in ethical and physical decline:

We have been erring since the beginning. We made a mistake when we disarmed people. We made a mistake when we made our fort walls defenseless. We made a mistake when we trusted to our foes. There can never be a peace treaty between a weak unarmed party and the heavily armed enemy. In such a case, there will only be surrender and submission. 
..... Had we fought; we wouldn't have lost that much... Behold. The destruction is not limited to people's homes and livelihood, but also reaches out to their souls and hearts. (Wannous, 1993, pp. 455-6)

This final verdict by Ibn-Mufleh may betray conscious didacticism, on the part of the playwright, who vehemently preaches for the absolute need for both fortified borders and a free civil society. However, this forthrightness does not detract from the playwright's increasing intellectual and artistic growth which has broadened his horizon and allowed him to proportionately include the perspectives of his ideological opponents.

With the play's contemporary relevance, the conflicting ideologies are used to demonstrate the state of modern malaise in Syria and its incapacity to deal with adversity. In an interview with Maher al-Sharif, Wannous explains that his "aim was to introspect about a historical anecdote and explore the responses of the strata of statesmen, academics and the common people in relation to catastrophe" (Wannous, March 1994, p. 668). To that end, he combines real and fictional characters and, endows them with complexity. Avoiding stock characters of good and evil, the playwright provides characters with a "wide margin of freedom, initiative and democracy" (Wannous, March 1994, p. 668). With the idea of contemporary relevance of historical events in mind, one can notice parallels with diverse contemporary vices. For example, there is analogy between the Sultan of Egypt forsaking Damascus and the Middle Eastern despots seeking their own positions in time of national crisis. Hence, the play censures modern time Arab despots for prioritizing their offices over the safety of their people. Similarly, the character of the greedy merchant, Dulama, points to the modern stratum of rich merchants who, fearing for their possessions, wish to surrender the city to invaders. The play also presents a critique of modern religious leaders who maintain their statuses by obeying the dictator or the Sultan. Most importantly, in the character of the famous historian Ibn Khaldūn, Wannous voices a critique of the intellectual elites, who are entrenched behind their academic neutrality and refrain from involvement in timely issues. In Al-Tadheli, there is a critique of the pedantic clergy who, despite being well intentioned, prohibits the freedom of thought and philosophical introspection. Thus, all these historical personas are meant to comment on all contemporary categories of potential leaders who, by taking the wrong stance, are contributing to chaos and destruction. The contemporary relevance together with the plurality of voices point to Wannous's growth in adopting the concepts of freedom and democracy.

The newly formed concept of democracy is integrated within the very structure of Historical Miniatures. "The play is not built according to a plot procession, but a mosaic made of miniatures" (Wannous, March 1994, p. 668). Each miniature is a scene that displays a wave of intricate events and details discussing various responses to the menace awaiting Damascus. In lieu of a plot, the play uses narratives interwoven with and interrupted by debates which delineate clearly the "conflicting interests and different viewpoints" (Wannous, March 1994, p. 668). 
Showcasing divergent perspectives, this complex structure proves to be an adeptly expressive tool for a democratic platform.

Characters voicing these diverse thinking patterns are neither condemned nor condoned. Instead, each character at the opposite end of the spectrum is endowed equally cogent argument. Hence, intellectual complexity arises, and characters stand up to test the validity and/or folly of their claims. It is the balanced duality of perspective that is the characteristic feature of the dramaturgy of the later period. For example, the dichotomy between the Salafism and liberalism of both leading clergy- Sheikh Burhaneddin al-Tadheli and Sheikh Jamaleddin al-Shara'iji is a most impartial presentation of conflicting theological views. The venerable Tadheli is a pious patriot, who, like Joan of Arc, receives a spiritual revelation instructing him to defend Damascus and secure its freedom. He wholeheartedly leads militant strife to defend the lives and honor of his countrymen against the Tartar invasion and inspires many honorable freedom fighters such as his daughter Su'ad and the scholar Sharafeddin. He eventually dies as a revered martyr. Due to his selfless dedication to the sovereignty of his people, he is viewed as an empathetic protagonist. Yet, he is a force of darkness as he incriminates freethinking. He condemns his theological opponent the Sufi philosopher, al-Shara'iji, because of the latter's free speculation on matters of faith and fate. It is noteworthy that al-Shara' iji is, in part, a self-dramatization of the playwright who sees himself as a martyr for the cause of reasoned debate and honest dialogue. The fundamentalist, alTadheli, considers al-Shara'iji's logical reasoning of theology as a blasphemy to be punished by jail. Wannous's truth here is complex due to al-Tadheli's ambivalent characterization swaying between the two extremes of his empathetic patriotic strife and repulsive intolerance of intellectual freedom. Such a binary opposition in religious implications has contemporary relevance to the later rise of Salafi/takfiri Jihadist trend and their conflict with Islamic free thinkers in the modern Muslim world. The play utilizes the conflicting emotional appeals of al-Tadheli's dedication to his city's sovereignty and al-Shara'iji's dedications to freedom of thought within Islamic faith. The playwright's role here is to enlighten the audience of the need to see the bigger picture of Islamic fervors that are the dynamos of the masses. In this instance, he tips the scale in favor of liberalism as he places the Jihadist liberating fervor proportionately within the larger picture of intellectual oppression.

The duality of perspectives is dramatized again in all three miniatures. For example, Ibn Khaldūn and his disciple Sharafeddin are foils who bring to attention the academics' ethical responsibility towards public affairs. Ibn Khaldūn, the celebrated scholar and historian of the $14^{\text {th }}$ Century Muslim world ${ }^{\mathrm{i}}$, is presented in this play as a controversial character whose academic neutrality is most praiseworthy, but his disengagement in the welfare of the city is most objectionable. His name relates to uncontested pride in Muslim past, shown clearly in Su ad's respect towards him while reverently massaging his feet. (Wannous, 1993, p.360). To present this scholar in a critical perspective would be unsettling for audience who are used to unquestionably celebrating icons of a glorious past. Ibn Khaldūn's commitment to utter neutrality in recording history is contested by his disciple Sharafeddin who calls for an agency in making history. In his 
historical manuscript, Ibn Khaldūn refers to Tamburlaine respectfully as 'Prince Tamr' and refrains from condemning his conquest of Damascus. He defends his academic detachment in his words: "We are documenting history, not writing scathing literature" (Wannous, 1993, p. 360). Although highly acclaimed, Ibn Khaldūn is severely criticized for being too emotionally detached, for seeking the safety of his manuscripts, and for having no moral scruples about giving his loyalty to the conqueror. When he realizes that Tamburlaine will win the battle, he joins a convoy of Damascus elite, presents him with expensive gifts, plays the sycophant and secures his own personal and academic safety. Ibn Khaldūn's characterization creates a controversy about the role of intellectuals. What good does knowledge do if it cannot be applied to reality in order to improve it? Should educated people be neutral or take part in historical action? Should the educated elite serve authority or move the society? Such questions are deeply connected to the playwright's concern for democracy. If Wannous has stopped instigating people to start a revolution, he is now promoting free thinking and highlighting the importance of education in raising awareness and enlightening people. Through this duality of Ibn-Khaldun and Sharafeddin's perspectives, Wannous puts his weight in the argument as he rejects utter neutrality and calls the educated elite to take an active role in serving people and determining the destiny of the nation.

A third plurality of perspective relates to the double burden of safeguarding both sovereignty and democracy at the same time. The dialogues among Azdar, Sharafeddin and Ibn Tayeb about colonization and dictatorship present conflicting views on the exigency of protecting the state versus homeland. Azdar, the Prince of the Castle, defends Damascus city, against the Tartar invasion, and fights to safeguard the rule of the Sultan equally ardently. For him, patriotism means unconditional allegiance to both homeland and the ruler. He, thus, equates the safety of the nation with the security of the state. However, the anti-Sultan opposition, represented in Ibn Tayeb, vilifies the Sultan for withdrawing and prioritizing his rule. He changes throughout the play from demanding the right to fight the tartars to calling for surrender in order to limit bloodshed and destruction. Sharafeddin, on the other hand, opposes both the Sultan rule and the foreign invader, thus, making a statement against both dictatorship and colonialism. The plurality of political opinions in the voices of the three characters Ibn Tayeb, Azdar and Sharafeddin create a democratic debating platform on stage, where the dialogue develops freely. The multiple facets of truth depict a nation paralyzed, firstly by totalitarianism, and secondly by colonization. Wannous links these two evils as cause and effect: Totalitarianism and the lack of democracy historically created squabbles among people and impeded their union. The result is utter defeat and a massacre on the hands of the Tartars. The causal relation between totalitarianism and colonialism and the need for democracy in this play have contemporary relevance in the priority given to the rule of Al-Assad over the security and welfare of the Syrian people. This mistaken fusion of the two concepts marks the dictatorship of Hafiz Al-Assad (1971-2000), and is clear in the famous motto 'Assad's Syria'. Similarly, the same is true for the later totalitarianism of President Bashar Al-Assad, with the catchphrase of "Al-Assad or we burn the country," which became the leitmotif of Assad supporters while extinguishing the revolution that started in 2011 (Dagher, 2019). Azdar's justification for this dictatorship and police state has its contemporary relevance in support of Al-Assad

Arab World English Journal for Translation \& Literary Studies 13 ISSN: 2550-1542 | www.awej-tls.org 
totalitarianism. Moreover, the multiplicity of the three voices in this play seems to anticipate the much later conflicting strife in Syria against the Assad dictatorship and the consequent hegemony of foreign powers such as Russia and Iran. It seems that Wannous is prophetic in linking the struggle for freedom to both in-state democracy and the sovereignty of the nation. Considering all the previous dichotomies and multiplicities, truth in Historical Miniatures has multiple facets. The dramatist allows his characters cogent argument to present their perspectives and convictions. With the uncontestable historical truth of the destruction of Damascus, the author does not draw conclusions or resolve the multiple arguments. He dramatizes the conflicting views, gives them equal weight, and leaves it to the historically aware audience to process ideas. Allowing for such controversies, Wannous is creating a democratic experience where every perspective is allowed full expression.

\section{Third Stage: New Aesthetics in Exploring the Individual and Society}

The more Wannous internalizes freedom, the more he shifts towards a freer expression of the individual and libidinal desires, in such plays as Miserable Dreams (1994), Rituals of Signs and Transformations (1993-4) and Drunken Days (1997). Reassessing his earlier Marxism, Wannous stopped marginalizing the self and experienced more elation in dramatizing his own passions. With his knowledge of impeding death, Wannous developed the urgency to write more compulsively and more freely. Such an elation is observed by many critics such as Shakhsoukh:

For the first time, Wannous feels the joy of writing. He used to deny himself expression as he had believed that the individual's suffering is too personal to write about. Focusing mainly on historical awareness, he had bypassed his own feelings, thus he felt divorced from himself and out of his skin (1998, p. 68-69).

Shying away from politicizing the masses in the later period, he invents new aestheticism and new means of expression, a theater that bravely explores the individual and society.

His main concern in this period is to live life to the full, unshackled by social restraints. His other concern is unmasking the social forces that curb individuals and conceal their true selves. The antagonists are men representing forces of social and political backwardness and corruption. For example, through Kazem and Faris, in Miserable Dreams, he critiques toxic masculinity. Through the Mufti, Chieftain of noblemen [Naqīb alAshraf] ii, and chief of police, in Rituals of Signs and Transformations, he censures the corruption of politico-religious establishment. Through Sanaa's husband, in Drunken Days, he showes his dismay with the bourgeois society in transition between conservative Arabic culture and openness to the west. In contrast, it is women who become centerstage characters, who express the human longing for freedom. In these three plays, the female characters Ghada, Mary, Mu'mena /Almassa and Sanaa are empathetic protagonists yearning to live life to the full through their expression of libidinal desires. These women are repressed by social taboos imposed on their gender. Due to ubiquitous social oppression, they are deprived from the agency to develop self-awareness and to act on their 
problems. When the female, at last, becomes aware of her internalized sexual repression and finds the will to rebel, her quest for freedom is most tragically aborted.

The pervasive yearning towards fulfillment of sexual desires in Wannous's last plays is, in effect, not inseparable from the playwright's overall concern with social justice and political reform. Miserable Dreams portrays the debilitating effect of social oppression on women. Having contacted a venereal disease from her husband, Mary is deprived of procreation and connubial pleasures. Ghada, on the other hand is abused psychologically and physically by an ignorant unethical husband, Kazem. Working as a morally degenerate government informer, he bars her from independent thinking and forces her to worship him as a god. Disgusted with her husband's vulgarity, she fantasizes about Mary's tenant, an offstage college student who has the potential of refinement and education. Simultaneously, Mary imagines the tenant to be her unborn child, a surrogate of productivity and hope. As both husbands conspire to evacuate the tenant, Mary and Ghada desperately rebel against their husbands and plan to poison them. However, their hopes for liberation are crushed with the ironic turn of fate as Ghada's child, by mistake, ends up consuming the poison. Thus, Ghada and Mary's lame revolt against life-long suppression meets a tragic end. Although their wish to relieve their oppression is a valid human aspiration, they lack the proper tools to effectuate change, and they can only think of a panacea through murder. It is ironic that Wannous who was in his middle period aiming at instigating rebellion, is dramatizing here the tragic consequence of a poorly planned revolt that, just as the later Syrian revolution in 2011, only perpetuated more destruction and oppression.

Identifying with the female gender and delving into the individual desires in the later period, Wannous does not relinquish his mission of spreading political awareness. For example, the female protagonist,Ghada, shares with the playwright his predilection for the Egyptian president Jamal Abdulnasser who championed the concept of Arab union. She perseveres through male hegemony and keeps up her intellectual autonomy by writing letters to her brother, resisting her husband's politics and dreaming of a better world in the company of an educated young male neighbor. Ghada's struggle for intellectual autonomy and self-fulfillment within an oppressive milieu is parallel to Wannous' own resistance for awareness and freedom from oppressive regimes.

Wannous's female characters contribute to an autographical strain in his later writing where the political and the individual concerns are fused. In his masterpiece, Rituals of Signs and Transformations, his identification with women becomes more evident as Mu'mena, the female protagonist, while seeking personal freedom, provides a critique of the politico-religious establishment. The play, which is set in Damascus at the end of the $19^{\text {th }}$ century, revolves around a storyline borrowed from the memoirs of Fakhri al-Baroudi. The Mufti of Damascus quells two notables- the Chieftain of Noblemen and the chief of police- and reigns. The cunning Mufti seems to forgo a personal grudge against the Chieftain and helps him out after the chief of police arrests the Chieftain under the charge of indecency with a concubine. Having the Chieftain in his grip, the Mufti demolishes the chief of police as he has dared to defame a prominent member of prophet's 
descendants. Evading public anger, Wannous claims not to aim at censuring any historical religious public figures or establishment. Instead, he contended that the characters in the play are individuals who have "their personal struggles and desires" (Wannous, 1994, p. 469). However, the action of the play departs from the original storyline of the memoir and revolves around Mu'mena, the Chieftain's wife, whose already simmering anger is ignited by her husband's infidelity and the Mufti's slyness. As Mu'mena agrees to acquit her husband by switching roles with the concubine in prison, she seizes the opportunity to break free, get a divorce and pursue a life of unrestrained desires and pleasures. Breaking away from the restrictions imposed on her by her husband, her father, and the social norms, she follows her whims and transforms to Almassa, a fille de joie. As a child, she witnessed her respectable father hypocritically indulging himself in connubial pleasures with the housemaid. Now, it is her very husband that is practicing the same licentiousness and hypocrisy. As a result, she rebels against sexual repression and double standards that connect honor exclusively to female chastity. She wants to explore the full range of pleasures and physical desires available to the human body regardless of social or ethical restrictions.

The transformation of Mu'mena's name, that denotes piety, to Almassa, that means a shiny diamond, is a declaration of rebellion against conventional taboos. This transformation is parallel to the playwright's later desire for emancipation from all constricting ideologies. In his evolving freedom, while he is counting down his days, he introduces personal topics which he never felt easy to discuss. The notion of freedom now expands beyond the economic and political to include the social and the personal. In her poetic imagination, she sees that her divorce and consequent fall into "temptation" will allow her to "soar in space as a bird, the wind and sun rays" (Wannous, 1993-4, pp. 553-4). The poetic language with which she expresses her transformation bypasses taboos and sanitizes her wish to be united with her inner self: "I yearn to cut the coarse fiber ropes that have been tearing my flesh and oppressing my body, ropes pated with fear, decency, chastity and self-loathing, of sermons, verses, warnings, proverbs, and the instructions of ancestors" (Wannous, 1993-4, pp. 553-4). She wants her body to be as free as "flowers, leaves, moon, grass, gazelles, springs, light and everything alive in this world" (Wannous, 1993-4, p. 554). Uniting herself poetically with aspects of nature, Almassa presents her freedom allegorically and acquits herself from moral condemnation. While collapsing, having been stabbed by her brother, she elevates herself to the level of mythical fables:

Oh Safwan, I am a story and a story cannot be killed, I am an obsession, longing and seduction that you cannot kill with your dagger... My story will blossom now just like the orchards after a rainy winter. Almassa will grow and spread, she will spread with the thoughts, with the obsessions and stories.. stories.. sto.. ( Wannous, 1993-4, pp. 596-597)

While seeking her freedom, Mu'mena /Almassa unravels the complexities and hypocrisies lying at the heart of an austere and, at the same time, dissolute society. The main idea of the play is the uncovering of the way social norms tend to change and deform human nature. Wannous in this play identifies with his female protagonist. Almassa's longing for fulfillment and freedom belongs 
to the dramatist himself. The release of the self from ideological framework in the later plays, as Ali Souleman points out, led to the emergence of the private space of the individual and the appearance of a "recognizable autobiographical elements" $(2015$, p. 1)

Representing the self through a female protagonist is to be encountered again in Wannous's last play Drunken days, as Sanaa's private hedonistic tendency conflicts tragically with the expectations of a confining society. Imprisoned by harsh rules and taboos, Sanaa is commodified and married off to a rich husband for a mutual family business agreement. Like the unmasking of society in Rituals, the grandson unravels hidden secrets in the family past. His grandmother, Sanaa, had eloped from her husband and led a life in which she and her lover celebrated connubial pleasures and deep emotional ties. Such an episode revealed the social complexities of an era at the beginning of the twentieth century when Syria and Lebanon were transitioning from Arabic tradition to French modernity brought about by colonialism. As the affluent family was starting to accept the French lifestyle and cast away their traditions, Sanaa's elopement shocks the husband and makes him revert to his old lifestyle. Freedom brought by modernity liberated Sanaa from commodification and suppression only for a while, but she must meet her own duties as a mother. She gets out of the cocoon of her connubial happiness to find that her elder son is so scandalized that he commits suicide. Realizing that her elopement has brought shame and trauma to her children, she abandons her marital heaven and lives on as a hermit. In this last dramatic piece, Wannous expresses the malaise of society as experienced by women. He had shifted from dramatizing the tyranny of autocracy and police state to presenting the cruelty and hegemony of a collective space that deprives the individual from personal freedom.

\section{Conclusion}

Wannous in his later plays 1989-1997 evolved intellectually and artistically as he broached new aesthetes and a freer horizon of ideas in his theater. After his long commitment to his innovation of the theater of politicization in the middle period plays (1968-1978), he was disillusioned with the ability of the theater to effectuate a revolution. However, he maintained his belief in the role of creative artists in combating oppressive environments and creating atmospheres of intellectual freedom. In his late period, he realized that the theater could only have an enlightening and educating role. In his later plays, The Rape (1989), Historical Miniatures (1993), Miserable Dreams (1994), Rituals of Signs and Transformations (1994), and Drunken Days (1997), he advocated for intellectual and individual freedom. Internalizing this freedom, Wannnous democratized his dramatic text and allowed for plurality of voices. He abandoned his earlier didacticism and dispersed a multiplicity of ideas by endowing characters of opposing stances equal empathy, cogency and grandeurs. Moreover, women become central empathetic characters who take center stage and manifest undeniable self-identification on the playwright's part.

Wannous realized that his earlier commitment to Marxism had been counter-effective for his democratic aspiration, as it had deterred him from dramatizing the individual, a literary practice which was thought of as bourgeoise indulgence. Reassessing his earlier stances, he realized that 
promoting individuality is vital for advocating for a free civil society, which is in turn necessary to safeguarding the society from totalitarianism. Hence, he freed himself from the dogmas of isms and delved into the self, portraying the individuality of his characters, their psyche, aspiration, desires and conflict with society. The more aware of his approaching death, the braver Wannous was in facing his inner sensors and breaking away from oppressive ideologies and social taboos. This transformation manifested itself in his plays in the growth of a democratic spirit represented in the equality of opposing voices, the rise of individuality, depth and richness in characterization, the presence of libidinous dimensions, and the presence of women as protagonists.

\section{About the Author}

Samar Zahrawi received her PhD from the University of Leeds, U.K. in Modern Drama in 1992. She taught modern drama at Al-Baath University, Syria, and King Saud University, KSA. Currently, she is an Associate Professor of Middle Eastern Studies at Sam Houston State University, Texas, USA. Having a background in English and comparative drama, her current research interest is Arabic drama, Arabic culture, and translation studies.

ORCid https://orcid.org/0000-0002-6897-523X

\section{References:}

Abboud, M. (2008). Sadallah Wannous: Rebel, dreamer, and enlightener. Damascus: Festival of Damascus Arab Capital of Culture.

Al-' Anezi, A. N. (2006). An Analytical study of the theatre of the Syrian playwright

Sa'adallah Wannous, with particular emphasis on the plays written after 1967 war.

University of Sheffield, UK, unpublished dissertation, retrieved from

http://etheses.whiterose.ac.uk/3080/1/434995.pdf on 09-09-2015

Dagher, S. (2019). Assad or we burn the country: How one family's lust for power destroyed Syria. NY: Hachette Book Group.

Ilyas, M. (summer 2000). "Al-hayat masrah tijari tuzihahu al-kitabah: hiwar[Life is a commercial theater geared by writing]". Al-Karmil, 64.

Kahf, M. (Spring 2001). "The silences of contemporary Syrian literature”. World Literature Today. Vol 75 Issue 2. 224-236. also accessed on Sep 10, 2014, from Full-text Online Library, 118 http://www.thefreelibrary.com/The+silence+of+contemporary+Syrian+literature.a080500168.

Sakhsoukh, A. (1998). Oghniyat al-raheel al-Wannousiyyah [The departure songs of Wannous: A study in the theater of Sadallah Wannous]. Cairo: Egyptian Lebanese Publishing house.

Souleman, A. (Spring 2015). "Staging the self: Autobiography in the theatre of Sa'dallah Wannous". Arab Stages, Volume 1, Number 2

Wakim, J. (2013). The struggle of major powers over Syria.UK: Ithaca Press.

Wannous, S. (1969). Al-fill ya malek al-zaman [The king's elephant]. In Wannous, S. (2004). Ala'mal al-kamila [The complete works]. Beirut: Dar al-Aadab, vol I, pp. 553-579.

Arab World English Journal for Translation \& Literary Studies 
Wannous, S. (1970). Bayanat li masrah 'Arabi jadid [Manifestoes for a New Arab Theater] in Wannous, S. (2004). Al-a'mal al-kamila [The complete works]. Beirut: Dar al-Aadab, in vol III, pp. 9- 239.

Wannous, S. (1973). Sahra ma 'a Abi Khalil al-Qabbanī [Soiree with Abi Khalil al-Qabbani]. In Wannous, S. (2004). Al-a'mal al-kamila [The complete works]. Beirut: Dar al-Aadab, in vol I, pp. 685-784.

Wannous, S. (Feb 2. 1986) "Hawl al samt.wa Ma' souliyyat al muthaqqafin [About silence and the responsibility of the educated]", Al-Hurriya. In Wannous, S. (2004). Al-a mal alkamila [The complete works]. Beirut: Dar al-Aadab, in vol III, 447-460.

Wannous, S. (1989). Al-ightisāb [The Rape]. In Wannous, S. (2004). Al-a'mal al-kamila [The complete works]. Beirut: Dar al- Aadab, vol II, pp. 63-189.

Wannous, S. (1990) "Isterdad Taha Hussein [Retrieving Taha Hussein]", Qadaya wa shahadat. In Wannous, S. (2004). Al-a 'mal al-kamila [The complete works]. Beirut: Dar al- Aadab, vol. III, po. 475-494.

Wannous, S. (1993). Munamnamat tarikhiyya [Historical Miniatures]. In Wannous, S. (2004). Al-a'mal al-kamila [The complete works]. Beirut: Dar al-Aadab, vol II, pp. 317-466.

Wannous, S. (March 1994). "Sadallah Wannous wa Munamnamat tarikhiya: Hiwar ma'a Maher al-Sharif [Sadallah Wannous and Historical miniatures: Interview with Maher al-Sharif]". Riwayāt Al-Hilal no. 543. Cairo. In Wannous, S. (2004). Al-a'mal al-kamila [The complete works]. Beirut: Dar al-Aadab, vol III, pp. 662-685.

Wannous, S. (1994). Aḥlam Shaqiyya [Miserable Dreams]. In Wannous, S. (2004). Al-a'mal alkamila [The complete works]. Beirut: Dar al-Aadab, vol II, pp. 467- 598.

Wannous, S. (1993-4). Tuqūs al-isharat wal-tahawulat [Rituals of signs and transformations]. In Wannous, S. (2004). Al-a'mal al-kamila [The complete works]. Beirut: Dar al-Aadab, vol II, pp. 467- 598.

Wannous, S. (1997). Ayyam makhmūra [Drunken days] Damascus: al-Ahali.

Wannous, S. (2004). Hawamesh thaqafiyya 2 [Cultural margins 2]. In Wannous, S. (2004). Ala'mal al-kamila [The complete works]. Beirut: Dar al-Aadab, vol III, pp. 467- 780.

\section{Notes}

i Abū Zayd 'Abd ar-Raḥmān ibn Muḥammad ibn Khaldūn al-Haḍramī; 27 May 1332 - 17 March 1406) was a leading Tunisian Arab historiographer and historian, best known for his book the Muqaddimah [Introduction]. He is considered as one of the greatest philosophers of the Middle Ages who contributed to modern disciplines of historiography, sociology, demography and economics.

ii The government position of the Chieftain of noblemen [Naqīb al Ashraf], in various Islamic Empires, refer to the head of the descendants of Prophet Mohammed, who enjoyed certain privileges and legal immunity. 